Document downloaded from:

http://hdl.handle.net/10251/141635

This paper must be cited as:

Mateo-Guerrero, C.; Hernández Fenollosa, MDLÁ.; Montero Reguera, ÁE.; Segui-Chilet, S. (05-2). Analysis of initial stabilization of cell efficiency in amorphous silicon photovoltaic modules under real outdoor conditions. Renewable Energy. 120:114-125. https://doi.org/10.1016/j.renene.2017.12.054

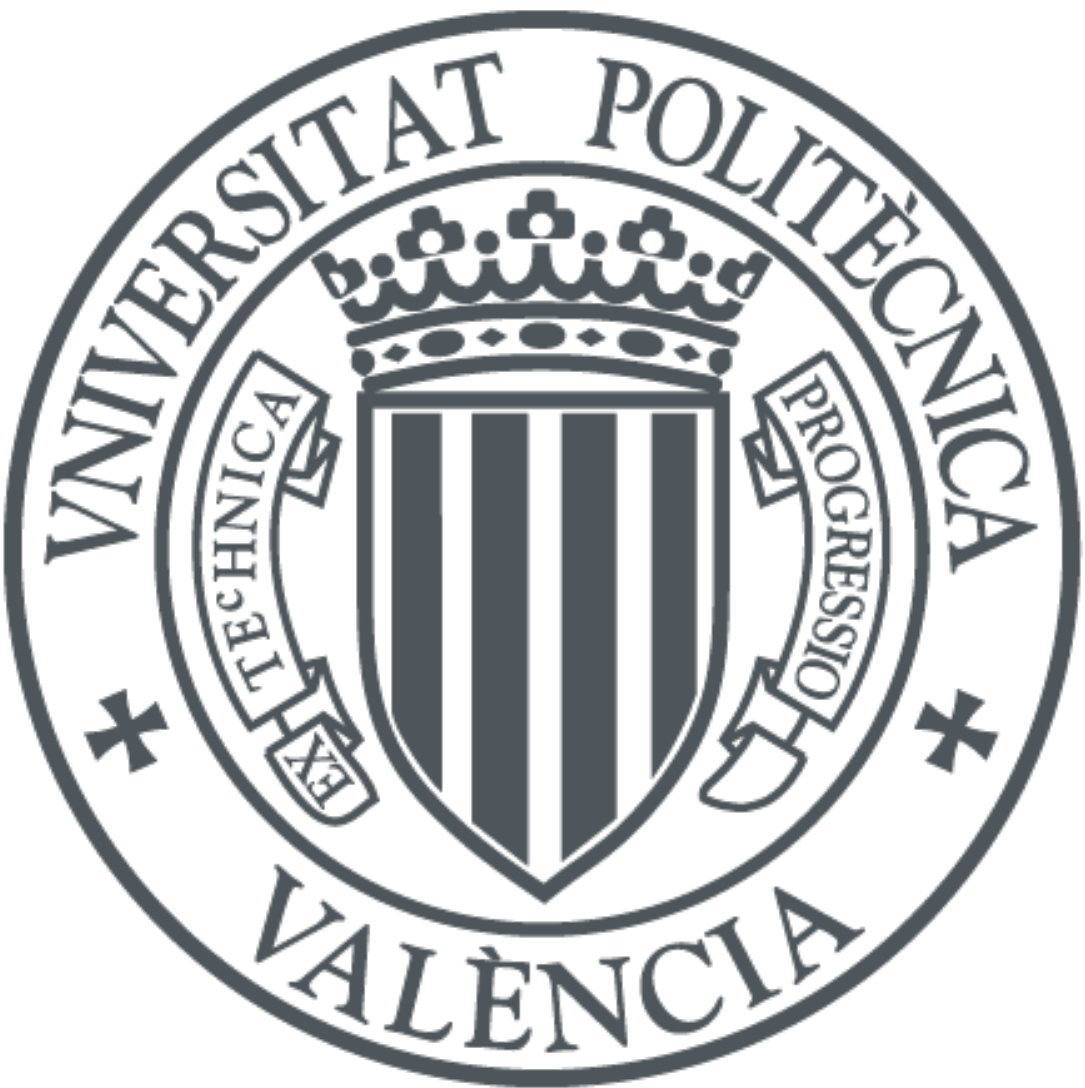

The final publication is available at

https://doi.org/10.1016/j.renene.2017.12.054

Copyright Elsevier

Additional Information 


\title{
Analysis of initial stabilization of cell efficiency in amorphous silicon photovoltaic modules under real outdoor conditions
}

\author{
C. Mateo, ${ }^{*}$ M.A. Hernández-Fenollosa, Á. Montero, S. Seguí-Chilet \\ Universitat Politècnica de València, Camino de Vera s/n, 46022 Valencia, Spain; \\ ${ }^{*}$ Corresponding author. Email address: cidmat@gmail.com (C. Mateo)
}

\begin{abstract}
This contribution presents a field study in which the initial stabilization of thin-film amorphous silicon (a-Si:H) is investigated. Two grid-connected a-Si:H photovoltaic plants have been monitored and analyzed under real outdoor conditions. A per-unit approach is proposed to compare PV plants with differences in their electrical characteristic and the start-up date. The representation of a normalized per-unit PV power versus the accumulated incoming irradiation reveals an evolution that can be characterized through an exposure-response function. By this function, two populations of defects in the cells are detected. It is found that the stabilization process in the first year of operation produces a decrease of $10 \%$ in the peak power, equivalent to a decrease of $0.5 \%$ in cell efficiency. The use of the accumulated PSH for conducting the analysis of the initial stabilization produces similarities that cannot be obtained if a time scale is used. These results provide a powerful tool for PV plant designers because they enable a prediction to be made of the time-scale stabilization response in terms of unitary power, correlated with the peak sun hours received.
\end{abstract}

\section{Highlights:}

PV efficiency stabilization in a-Si:H modules by means of exposure-response function.

Dependency of defect populations with accumulated irradiation.

Different seasonal effects after initial stabilization depending on start date.

Normalization approach to compare different a-Si PV plants.

Cell efficiency comparison using flash-report data and experimental values.

Keywords: Long-term PV measures, Staebler-Wronski effect, a-Si:H stabilization, real outdoor conditions, light induced degradation effect (LID) 


\section{Nomenclature}

\begin{tabular}{|c|c|}
\hline $\mathrm{AM}$ & Air mass \\
\hline a-Si:H & Hydrogenated amorphous silicon \\
\hline GI & In-plane global irradiance $\left(\mathrm{W} / \mathrm{m}^{2}\right)$ \\
\hline$I_{M P P}$ & Maximum Power Point current (A) \\
\hline$I_{S C}$ & Short-circuit current (A) \\
\hline $\mathrm{I}-\mathrm{V}$ & Current-Voltage curve \\
\hline LID & Light Induced Degradation \\
\hline MPP & Maximum Power Point \\
\hline NOCT & Normal Operating Cell Temperature \\
\hline$P_{M P P}$ & Power in the Maximum Power Point (W) \\
\hline$P_{M P P} p u$ & Normalized value of the MPP power $(\mathrm{pu})$ \\
\hline$P_{M P P_{S} S T C}$ & MPP power corrected to STC conditions (W) \\
\hline$P_{M P P_{-} S T C \_p u}$ & $\begin{array}{l}\text { Normalized value of the MPP power corrected to STC } \\
\text { conditions (pu) }\end{array}$ \\
\hline$P S H$ & Peak Sun Hour $\left(\mathrm{kWh} / \mathrm{m}^{2}\right.$ with an irradiance equal to $\left.1 \mathrm{~kW} / \mathrm{m}^{2}\right)$ \\
\hline PV & Photovoltaic \\
\hline pu & Per-unit \\
\hline $\mathrm{P}-\mathrm{V}$ & Power-Voltage curve \\
\hline STC & Standard Test Conditions \\
\hline$T_{a m b}$ & Ambient temperature $\left({ }^{\circ} \mathrm{C}\right)$ \\
\hline$T_{\text {cell }}$ & Cell temperature $\left({ }^{\circ} \mathrm{C}\right)$ \\
\hline TCO & Transparent Conductive Oxide \\
\hline$V_{M P P}$ & Maximum Power Point voltage (V) \\
\hline$V_{O C}$ & Open circuit voltage (V) \\
\hline$W_{p k}$ & Peak watt \\
\hline$\alpha$ & Current temperature coefficient $\left(\% /{ }^{\circ} \mathrm{C}\right)$ \\
\hline$\beta$ & Voltage temperature coefficient $\left(\% /{ }^{\circ} \mathrm{C}\right)$ \\
\hline$\gamma$ & Power temperature coefficient $\left(\% /{ }^{\circ} \mathrm{C}\right)$ \\
\hline$\eta$ & Efficiency $(\%)$ \\
\hline
\end{tabular}




\section{Introduction}

Profitably producing electricity from photovoltaic (PV) technology relies on the availability of PV modules that can operate for 25-30 years outdoors. International standards have been developed to test and characterize the level of reliability that PV modules achieve. Nevertheless, although these tests provide valuable information about PV module characteristics and performances, differences between the expected performances and the actual measured performances when exposed to outdoor conditions are observed. Studies of PV plant performance in outdoor conditions may give useful information that enables an understanding of real module behavior and the reasons behind differences in performance.

The efficiency of PV solar cells is another key point for the success of electricity generation from this renewable resource. PV technology development has been accelerated by several factors such as: its contribution to reducing global warming; its consideration as an environmentally friendly technology; an impressive fall of prices of PV cells; governmental support for renewable energies [1-4]. Around $92 \%$ of the PV market was shared in 2015 between the two most important crystalline silicon (c-Si) technologies: single-crystalline and poly-crystalline [5]. The rest of the market is shared among several thin-film technologies (a-Si:H, CIS, CISG, CdTe, etc.) [6-9] and other technologies obtained by a combination of different technologies (Tandem c-Si and a-Si, HIT, etc.). The main drawback of thin-film technologies compared to c-Si technologies is the lower cell efficiency, although some commercial thin film modules are reaching values similar to those obtained with poly-crystalline technology. Nevertheless, thin-film technologies needs less raw silicon (between 100 to 200 times less), less energy during manufacturing, and are easier to manufacture [10,11]. PV market information provided by the International Energy Agency shows that the production of thin-film modules in the period 2011-2015 has remained fairly constant [12].

The correction of the maximum power point (MPP) power to standard test conditions (STC) has created some interpretation difficulties for these modules. Apart from the influence of module temperature and ambient variables (common disruptive effects for all technologies) a-Si power rates depend on module history of sunlight exposure and on recent hours of sun radiation. Thus, apart from having an accurate procedure to measure module output current and voltage, a precise understanding of the module behavior operating in actual outdoor conditions is desirable. Only then, can a precise prediction be made of the power delivered by a PV power plant based on these modules. This contribution presents a field study of two PV plants based on a-Si:H modules, focusing the analysis in characterizing the initial behavior stage, defined as the transitory process ending when PV plant output power stabilization occurs.

Studies on the behavior of PV plants has led to an increasing interest in understanding the factors affecting cell efficiency and PV plant performance [13-15] in greater detail. Field experience in a-Si:H PV modules is the most extensive 
of all the thin-film technologies [16,17]. Knowledge obtained over the last three decades with a-Si:H manufacturing and aSi:H PV plants is now used in other emerging thin-film technologies: CIS, CISG, TeCd, etc.

a-Si:H cells present a given band-gap [18,19], a narrow spectral response [20,21], and relatively low absorption coefficients [22]. Just as in all PV technologies, the PV field long-term yield is influenced by several factors: cell operating temperature; front surface soiling [23,24]; mismatch losses [25]; cell aging [26]; and optical stabilization mechanisms [27].

One of the most important factors affecting the PV plant performance is the real operating temperature of the cell $\left(T_{\text {cell }}\right)$. PV module parameters under STC conditions are rated: $G I_{S T C}=1000 \mathrm{~W} / \mathrm{m}^{2}, T_{\text {cell } \_S T C}=25^{\circ} \mathrm{C}$, and $A M_{S T C}=1.5 \mathrm{AM}$. NOCT is a parameter given by the PV module manufacturer in the datasheet, with typical values varying from $41^{\circ} \mathrm{C}$ to 51 ${ }^{\circ} \mathrm{C}$ depending on the type of PV modules. For STC irradiance conditions, $T_{\text {cell }}$ is between $26.3{ }^{\circ} \mathrm{C}$ to $33.8^{\circ} \mathrm{C}$ greater than $T_{a m b}$. The parameter most affected in a solar cell by an increase in $T_{\text {cell }}$ is the open-circuit voltage (which decreases) [22]. Increases in $T_{\text {cell }}$ also lead to small PV current increases that cannot compensate for voltage drops, resulting in a reduction in the power delivered by the PV modules.

Losses due to front surface soiling depend mainly on the specific characteristics of the PV plant location. Typical loss values due to soiling can vary from $2 \%$ to $4 \%[23,24,28]$, with values that can reach $8 \%$ in locations with large quantities of dust - as in PV installations near cement factories, rural roads, or deserts. Some improvements in glass surfaces have been developed to reduce losses due to soiling [29].

Mismatch losses appear when the I-V curve of two or more serial connected cells in a module (or modules in a string) have different characteristics. These differences cause the total current of the module (or string) to be reduced to the level of the worst cell connected in the serial circuit [30,31]. The main issues related to mismatch losses are the following: optical stabilization in cells; anti-reflective coating impairment; fabrication defects; partial or total shadowing; or microcracks in the cell [32]. When cells that can produce a high current are connected in series with cells that produce a smaller current (for the same environmental conditions), current recirculation will cause an overheating in the low current cell and create hot-spots $[33,34]$.

The aging of PV cells is continuously present and is the most important factor in the long-term stabilization of semiconductor PV materials. This is produced for various reasons and including: anti-reflective coating aging [35]; variations in the resistances present in the PV module equivalent circuit [36]; and the natural daily temperature cycles that cells suffer. All these factors increase the number of defects in the structure of the cells, and cause a decrease in the efficiency that is commonly related to light induced degradation (LID) effects [37-40]. 
PV plants based on a-Si:H modules present a specific performance behavior. During the first tens or hundreds of hours of sun beam exposure, a-Si:H module efficiency is drastically reduced. Studies presented in [41-43] show that the reduction in the efficiency of the cell from its initial value is in the range of $20 \%$ to $30 \%$. The cell efficiency drop is ascribed to the creation of additional metastable defects in the absorber layer [44], caused by the LID effect, with the main contribution coming from the Staebler-Wronski effect [45]. After this initial efficiency reduction, a-Si:H modules exposed to outdoor conditions exhibit, over a long-time scale, an efficiency pattern that increases during summer months and decreases in the winter [46]. This is a seasonal (periodic) behavior with a small decrease in efficiency. These almost periodic variations are the result of the superposition of several seasonal effects:

(a) High operating temperatures in summer reduce the power generation of a-Si:H modules, and this is closely related to NOCT [47] and the power temperature coefficient, $\gamma$. The variation of the power generation related to the temperature is quantified in the following section.

(b) Thermal annealing effects enhanced by high summer temperatures increase a-Si:H cell efficiency [48]. These effects compensate the efficiency decrease caused by the Staebler-Wronski effect in the a-Si:H material.

(c) Seasonal spectral variations in solar radiation reaching the Earth's surface. The summer solar spectrum better matches the wavelength region in which a-Si:H cells respond $[46,49,50]$ and results in an increase in the shortcircuit currents [47] and, therefore, in increased energy generation.

(d) Since the solar altitude angle is higher in summer, sunlight travels less through the Earth's atmosphere (smaller AM values) and suffers less scattering loss. Scattering losses are more significant in the short wavelength range.

(e) When the series resistance is small enough, the efficiency of all PV modules increases with the irradiance [51]. Therefore, we can expect a slight increase in module efficiency in summer from this effect.

This paper analyzes the stabilization process of two different a-Si:H plants under real operating conditions. Both installations are located in Valencia, in different buildings of the Universitat Politècnica de València (UPV), with differing electrical and mechanical conditions. The analysis is performed over the data acquired by a monitor system during the first months of plant operations. The purpose of this contribution is the characterization of the plant stabilization process, identifying the length of time before the PV plant reaches stable behavior. PV plant efficiency as a function of time is parametrized with suitable functions and the physical mechanisms that could explain the observed efficiency pattern are discussed. 
The layout of the paper is as follows. In the following section the PV plants under study are described, detailing the modules used in the installation, specifying the conditions of each installation, as well as the monitoring system used to acquire the most significant variables. In the next section, the acquired data is presented, analyzed, and discussed to characterize and understand the stabilization process of each PV plant. The final section details the conclusions.

\section{Description of the PV plants and the monitoring system}

Two a-Si:H PV plants were built at the UPV with several aims. Firstly, as an excellent practical tool for training courses for students in the renewable energy field. Secondly, to increase energy production from renewable sources, in line with the UPV environmental management system. And thirdly, as a field laboratory to analyze the outdoor behavior of these PV plants. The PV plants are located on the roofs of two different buildings (Nexus and ETSID) of the UPV, some $200 \mathrm{~m}$ apart, with a similar height of $25 \mathrm{~m}$. Both PV plants are connected to the electrical power network of the buildings with PV inverters.

The PV module used in the installation is the EPV52, an a-Si:H module supplied by EPVSOLAR. The datasheet characteristics, percentage of the initial variation, and calculated maximum initial values are detailed in the three first rows in Table 1. The tolerance for MPP power is $\pm 5 \%$. The STC values are given by the manufacturer after the stabilization period. Maximum initial values were considered during the design of the PV field and the inverter compatibility study. The final four rows include average values of the different parameters obtained for each installation (first two rows show the ETSID PV plant and the last two rows show the NEXUS PV plant) from the corresponding flash-test report of the modules provided by the manufacturer. 
Table 1.

EPV-52 a-Si:H module characteristics obtained from datasheet and flash-test reports.

\begin{tabular}{|c|c|c|c|c|c|c|}
\hline & $P_{M P P}\left(W_{p k}\right)$ & $V_{O C}(V)$ & $V_{M P P}(V)$ & $I_{M P P}(A)$ & $I_{S C}($ A) & $\begin{array}{c}\text { Cell } \\
\text { efficiency }\end{array}$ \\
\hline STC module values & 52 & 60 & 45 & 1.15 & 1.44 & $5.54 \%$ \\
\hline Maximum initial variation & $20 \%$ & $10 \%$ & $10 \%$ & $15 \%$ & $10 \%$ & - \\
\hline Maximum initial values & 62.4 & 66 & 49.5 & 1.32 & 1.58 & $6.64 \%$ \\
\hline $\begin{array}{c}\text { Average values in modules used } \\
\text { in ETSID PV plant (from flash } \\
\text { report) }\end{array}$ & 58.7 & 61.41 & 45.58 & 1.28 & 1.53 & $6.25 \%$ \\
\hline Average variation in ETSID & $12.9 \%$ & $2.3 \%$ & $1.3 \%$ & $11.3 \%$ & $6.3 \%$ & $+0.71 \%$ \\
\hline $\begin{array}{c}\text { Average values in modules used } \\
\text { in NEXUS PV plant (from flash } \\
\text { report) }\end{array}$ & 59.7 & 62.09 & 47.23 & 1.26 & 1.527 & $6.36 \%$ \\
\hline Average variation in NEXUS & $14.8 \%$ & $3.5 \%$ & $5.0 \%$ & $9.6 \%$ & $6.0 \%$ & $+0.82 \%$ \\
\hline
\end{tabular}

Temperature coefficients also appear in the datasheet and are included in Table 2. NOCT temperature, which is not included in regular datasheets, has been obtained directly from the manufacturer.

\section{Table 2.}

Temperature coefficients and NOCT temperature for EPV-52 a-Si:H module.

\begin{tabular}{|c|c|c|c|}
\hline$\alpha(\% / K)$ & $\boldsymbol{\beta}(\% / \mathbf{K})$ & $\gamma(\% / \mathbf{K})$ & NOCT $\left({ }^{\circ} \mathbf{C}\right)$ \\
\hline+0.09 & -0.28 & -0.19 & 41 \\
\hline
\end{tabular}

The following expression establishes the approximate relationship between $T_{\text {cell }}$ and $T_{a m b}$ temperatures:

$$
T_{\text {cell }}=T_{a m b}+(N O C T-20) \frac{G I}{800}
$$

Power delivered by a PV module under specific $T_{\text {cell }}$ and global irradiance $(G I)$ can be calculated with the following expression:

$$
P_{M P P_{-} G I_{-} T_{\text {cell }}}=P_{M P P_{25}{ }^{\circ} \mathrm{C}}\left[1+\frac{\gamma \%{ }_{\circ} \mathrm{C}}{100}\left(T_{\text {cell }}-25\right)\right] \frac{G I}{G I_{S T C}}
$$

The installation on the roof of the ETSID building has 64 modules organized in 8 strings with 8 modules in series per string. Operation started at the end of July 2010. The MPP power of the installation is $P_{M P P_{-} E T S I D}=3328 W_{\text {pk }}$, calculated with the STC value of the module multiplied by the number of modules. The maximum initial MPP power can reach 3993.6 $W_{p k}$, calculated with the maximum initial values before stabilization. The MPP flash-test report power is $3756.8 W_{p k}$, as 
calculated by summing the $P_{M P P}$ values detailed in this document. All modules are mounted on a flat plane that is tilted $20^{\circ}$ (smaller than the optimum angle for that maximizes the yearly energy yield - which is around $34^{\circ}$ for Valencia) [52, 53]. The smaller tilt improves energy production during summer, when irradiance levels are higher. At the same time, the tilt was selected to reduce the wind load transmitted to the building, considering that the installation is mounted in one corner of the building, with a top height $30 \mathrm{~m}$ above ground, and without other surrounding buildings. The PV plant faces south with an azimuth equal to $-18.6^{\circ}$ (facing west), which is the same as the building and this enables a better integration of the installation on the roof and so a maximization of the peak power of the installation over the available surface. Fig. 1 shows the single-line diagram representing all the components present in the ETSID PV plant, showed in Fig. 2. Public access to the plant monitoring system is shown in [54].

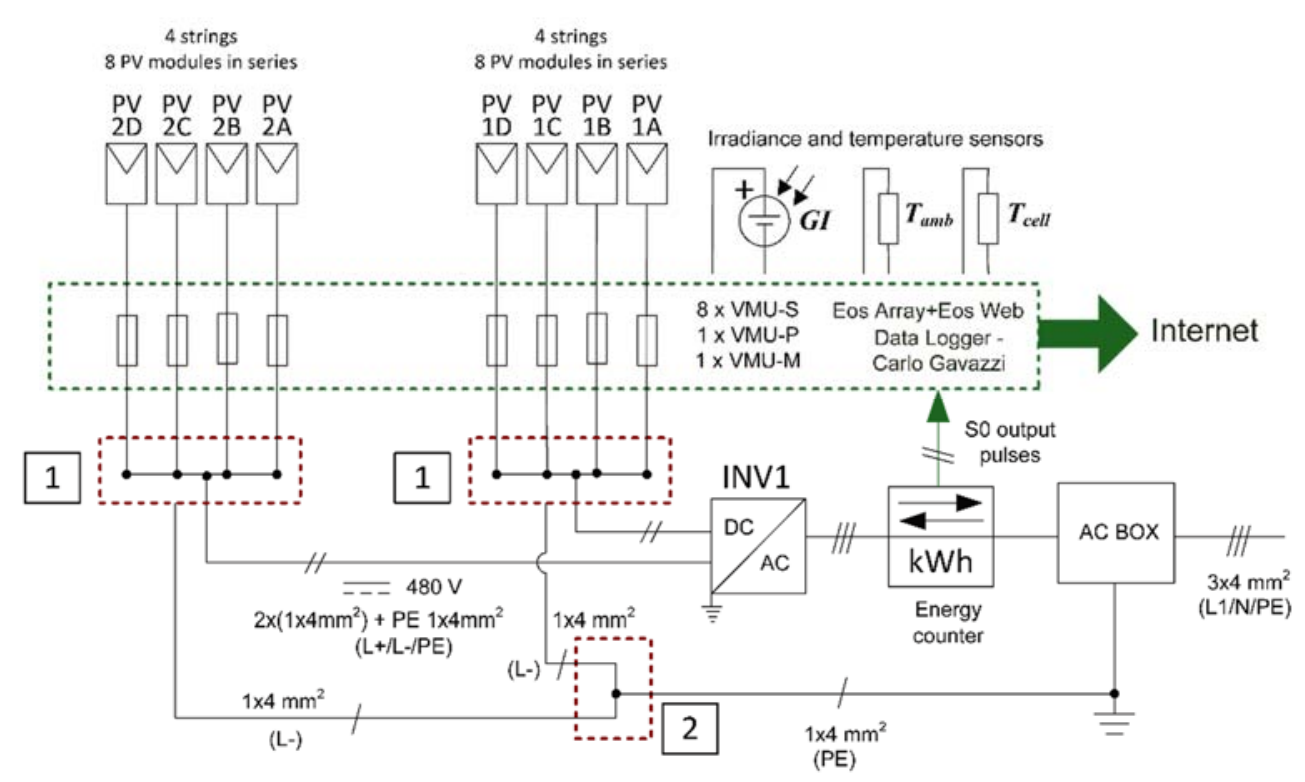

Fig. 1. ETSID PV plant electrical single-line diagram.

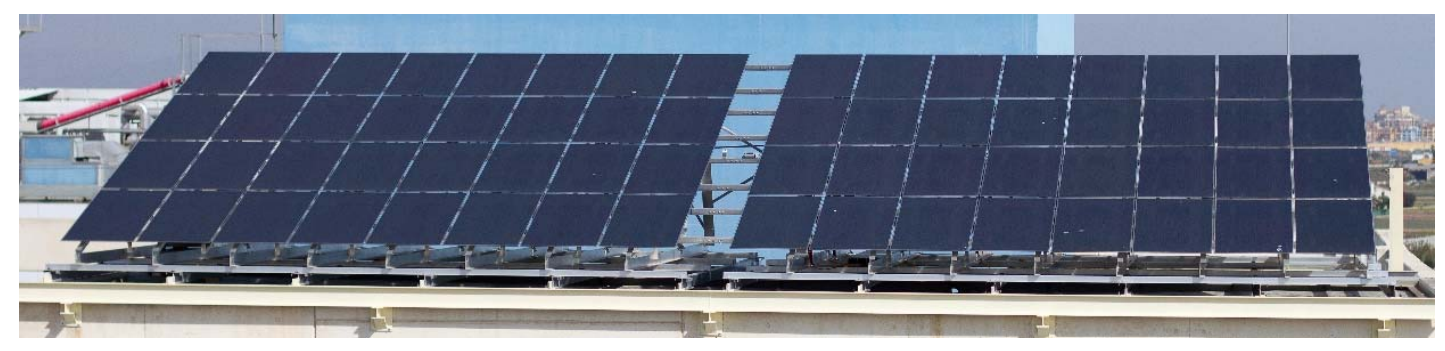

Fig. 2. ETSID photovoltaic field.

The Danfoss ULX3600HV grid-connected inverter used in the installation enables up to $3.9 \mathrm{~kW}$ in the PV field. The maximum initial MPP power (3993.6 Wpk) is slightly greater than the maximum power fixed in the inverter datasheet, but the inverter can modify the point of operation to protect itself from over-power and over-currents in the DC input. The 
inverter has two independent maximum power point trackers (MPPT), so the PV field is divided in two symmetric parts (each connected to its corresponding MPPT). Two combiner boxes are used for the parallel connection of the four strings (box 1 in Fig. 1). The DC/DC power converter that implements the MPPT algorithm also includes a high frequency transformer that provides galvanic isolation to the inverter. This feature is necessary because the PV module manufacturer recommends connecting the negative pole of the PV field to the electrical earth in order to avoid corrosion of the TCO. Such corrosion can appear if the voltage of the negative terminal of the photovoltaic field is negative with respect to earth [55]. Connection of the negative pole to earth is made in box 2 in Fig. 1. The second row of Table 3 shows the most important characteristics of this inverter.

\section{Table 3:}

Characteristics of the inverters used in the PV installations.

\begin{tabular}{|c|c|c|c|c|c|c|}
\hline Inverter model & $V_{d c_{\_} \max }$ & $V_{d c_{\_} \min }$ & $I_{d c_{\_} \max }$ & $P_{P V_{\_} \max }$ & $\eta_{E U R}$ & $\eta_{\max }$ \\
\hline $\begin{array}{c}\text { Danfoss ULX3600HV } \\
\text { (ETSID) }\end{array}$ & $600 \mathrm{~V}$ & $200 \mathrm{~V}$ & $14 \mathrm{~A}$ & $3900 \mathrm{~W}$ & $93.4 \%$ & $94.3 \%$ \\
\hline $\begin{array}{c}\text { SMA Sunny Boy } 1200 \\
\text { (NEXUS) }\end{array}$ & $400 \mathrm{~V}$ & $100 \mathrm{~V}$ & $12.6 \mathrm{~A}$ & $1320 \mathrm{~W}$ & $90.7 \%$ & $92.1 \%$ \\
\hline
\end{tabular}

The model selected can work with high voltages on the DC side, being suitable for thin-film modules that usually generate larger voltages than c-Si modules. To limit the maximum open circuit voltage to values smaller than $600 \mathrm{~V}$ under any operating conditions, the maximum number of EPV52 modules that can be connected to the ULX3600HV DC inputs is 8 in series per string. Initial over-voltages in a-Si modules combined with low $T_{a m b}$ are the worst conditions to consider for the design of the strings.

The installation also includes an AC panel with the corresponding breakers for limiting maximum inverter output current and for protecting against indirect contacts due to residual currents. Furthermore, a monitoring system acquires and stores all the magnitudes necessary to verify the correct operation of the PV system.

The installation in the Nexus building uses 20 EPV52 modules and started its operation at the beginning of April 2011. The PV field has five strings, with four modules connected in series per string. The MPP power of the installation is $P_{M P P \_N E X U S}=1040 W_{p k}$, the MPP flash-test report power is equal to $1194 W_{p k}$, and the maximum initial MPP power can reach $1248 W_{p k}$. The installation faces south and the tilt is $30^{\circ}$. The five strings of the PV field are connected in parallel in a DC combiner box (box 1 in Fig. 3), in which the negative pole of the PV field is also connected to the earth of the electrical installation to avoid TCO corrosion problems. The output wires of the combiner box are connected to the DC input of the inverter, as shown in the single-line diagram in Fig. 3. Public access to the monitor system of this plant is in [56]. 


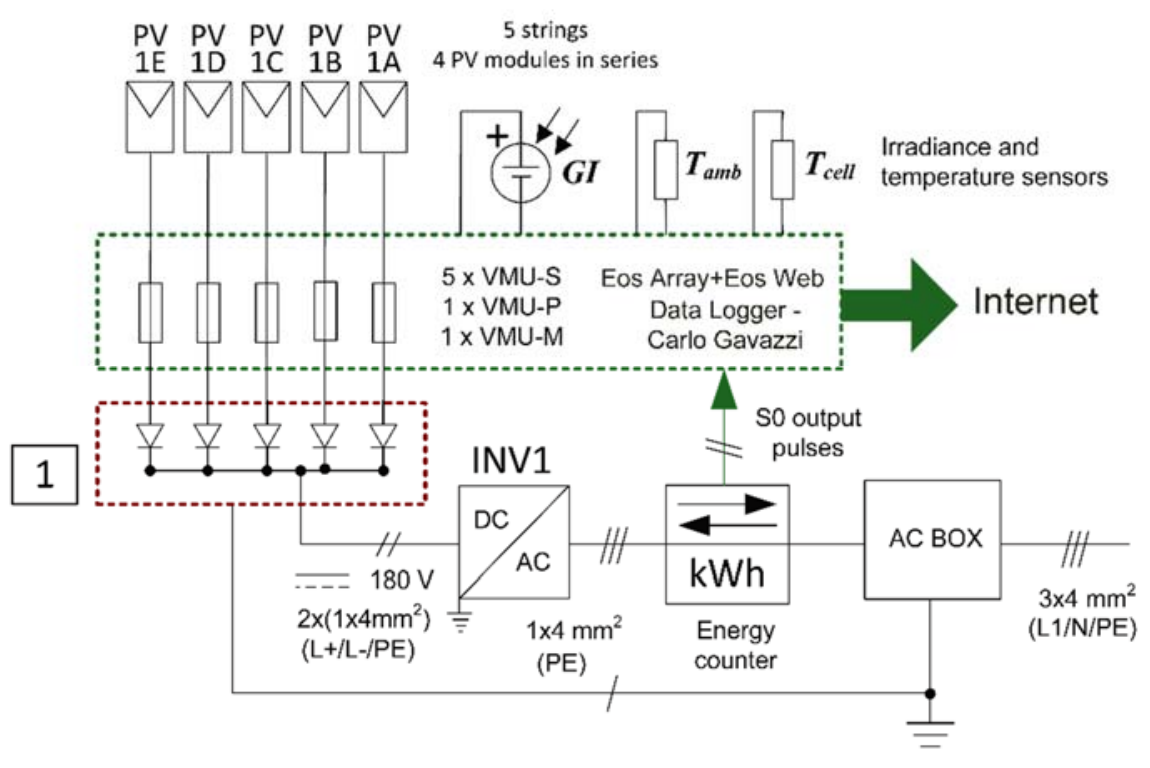

Fig. 3. NEXUS PV plant electrical single-line diagram.

The inverter used in this installation is the SMA Sunny Boy 1200. The key characteristics of this inverter are detailed in the third row of Table 3. The inverter includes a low frequency transformer in the AC converter output, enabling the grounding of the PV array negative pole. Comparing the inverters used in these installations, the use of a grid transformer in the inverter output decreases the efficiency of the conversion (and the performance ratio of the installation) by around $2.7 \%$ when averaged European efficiency $\left(\eta_{\mathrm{EUR}}\right)$ values are used.

Both installation fuses and diodes are connected in series in each string (box 1 in Fig. 1 and Fig. 3). Fuses are included by default in the Eos Array monitoring system and are intended for limiting the maximum current flowing through the strings. Diodes are included in the DC combiner boxes that are used to connect in parallel several strings before connecting to the corresponding inverter DC input. Diodes avoid the flow of reverse currents when several strings are connected in parallel. Protections on the AC side of the installations include an automatic breaker that limits the maximum output current, and a residual-current breaker used as protection against indirect contact (for safety).

A monitoring system is included in each facility to test and understand the performance evolution of both plants. Measures of string voltage and current, irradiance, $T_{c e l l}$, and $T_{a m b}$ are acquired. Both installations are monitored with an Eos Array data acquisition system (provided by Carlo Gavazzi). The monitoring systems include one VMU-S unit per string for the measurement of the string MPP voltage and current (five units for the NEXUS plant and eight units for the ETSID plant). Two VMU-P units are needed for the measurement of irradiance, $T_{\text {cell }}$, and $T_{\text {amb }}$ in both PV installations. The $T_{\text {cell }}$ sensor (Tempsol 1000 unit) is attached to the center of the back surface of a module by means of a self-adhesive that is included by the manufacturer. The sensor includes a heat conductor metal body with a Pt1000 sensor inside. The $T_{a m b}$ sensor 
(IKE 2000 1k unit) also uses a Pt1000 sensor that is encapsulated in a thermoplastic enclosure and located in the back space of the PV field - at some distance with respect to the module surface in order to correctly measure the $T_{\text {amb }}$ (under shadowing conditions). Both temperature sensors have a tolerance equal to $0^{\circ} \mathrm{C} \pm 0.3^{\circ} \mathrm{C}$ and class $\mathrm{B}$ accuracy according to EN60751. Solar irradiance is measured using a Cellsol 200 unit, that includes a small mono-crystalline cell that must be installed on the same plane as the PV modules. Typical sensor output for $1000 \mathrm{~W} / \mathrm{m}^{2}$ is around $75 \mathrm{mV}$, but each sensor includes a label detailing the calibration ratio that must be included in the configuration of the Eos Array monitor system for accurate irradiance measurement. The range measured by the irradiance is from 0 to $1500 \mathrm{~W} / \mathrm{m}^{2}$ and its accuracy is $\pm 5 \%$ (annual average). All the information from VMU-S and VMU-P measuring units is collected by the master module, the VMU-M unit. Every value stored in the VMU-M memory is the result of the average calculation, in a one minute interval, of the variables measured and sampled every two seconds. MPP power is calculated by multiplying the corresponding MPP voltage and current. The accuracy of the voltage and current values is equal to $\pm 0.5 \%+2$ digits, while the accuracy of the power values is equal to $\pm 1 \%+2$ digits). The MPP power multiplied by $1 / 60$ yields the DC energy produced by each string during the one minute interval. AC energy supplied by the grid-connected inverter is calculated from the pulses provided by the S0 output of an AC energy meter. The pulses are connected to the second digital input of a VMU-M unit. The performance ratio of the inverter can be calculated dividing the AC output energy by the DC input energy.

The use of a monitoring system oriented to the PV string enables analyzing the stabilization process for both aSi:H PV plants under real outdoor conditions $[57,58]$. Other important reference values of PV systems can be obtained using this monitoring system: performance ratio; reference yield; array yield; final yield; mismatch losses; etc.

\section{Analysis of the stabilization process due to LID effect in a:Si modules}

This contribution is focused on the analysis and characterization of the transitory process present in PV plants based on a-Si:H modules during the first hours of operation. A field study of two photovoltaic facilities has been completed to characterize the transitory process that ends when a stationary behavior is reached. The actual behavior of the photovoltaic plant is compared with the values supplied by the manufacturer. Module parameters used in this analysis are taken from the electrical data given by the manufacturer for each photovoltaic string (included in the real flash-test report for each module).

\section{Calculation of the normalized value of the MPP power under STC conditions}


To analyze the real power output and its stabilization, three data collections $\left(G I, T_{\text {cell }}\right.$, and $\left.P_{M P P}\right)$ were taken at different intervals of the day for each string ( 8 strings in ETSID and 5 strings in NEXUS). Irradiance values in all cases are greater than $700 \mathrm{~W} / \mathrm{m}^{2}$ in order to have reliable values. At the same time, the irradiance presents small variations around the interval selected $\left(\Delta G I<20 \mathrm{~W} / \mathrm{m}^{2} / \mathrm{min}\right)$ [59], according to IEC 61829:1995 and the expression used to calculate the STC power [60]. Eq. (3) enables obtaining the MPP power corrected to STC conditions $\left(P_{M P P} S T C\right)$ if operating conditions are known ( $G I$ and $\left.T_{c e l l}\right)$. This expression is going to be used for correcting the power values acquired with different operating conditions in the two PV plants under study. By using the average value of the $P_{M P P_{-} S T C}$ power for the three selected measures in a day, a value is obtained that is independent of the temperature and the instantaneous irradiance that affects the cell.

$$
P_{M P P_{-} S T C}=\frac{\frac{G I_{S T C}}{G I}}{1-\left(T_{c e l l}-T_{S T C}\right) \frac{\gamma}{100}} P_{M P P}
$$

A normalized value of the MPP power $\left(P_{M P P_{-} p u}\right)$ and the $P_{M P P_{-} S T C}$ power $\left(P_{M P P_{-} S T C \_p u}\right)$ are defined for each PV installation. It is possible with these parameters to compare both facilities at the same scale of value. Eq. (4) and (5) show how the normalization is performed:

$$
\begin{aligned}
& P_{M P P_{-} \_u}=\frac{\sum_{1}^{n} P_{M P P_{-} p u-S n}}{P_{\text {base }}} \\
& P_{M P P_{-} S_{T} C_{-} p u}=\frac{\sum_{1}^{n} P_{M P P_{\_} S T C-S n}}{P_{\text {base }}}
\end{aligned}
$$

Where $n$ is the number of strings per facility (eight in ETSID and five in NEXUS), and the base powers are $P_{\text {base } E T S I D}=P_{\text {MPP_ETSID }}=3328 \mathrm{~W}_{\mathrm{pk}}(64$ modules $)$ and $P_{\text {base } N E X U S}=P_{M P P_{-} N E X U S}=1040 \mathrm{~W}_{\mathrm{pk}}(20$ modules $)$. Fig. 4 shows the procedure followed to calculate the normalized power in each per-unit base. By means of the per unit system, the PV plant power differences in absolute values are converted to base values that enable easier comparison.

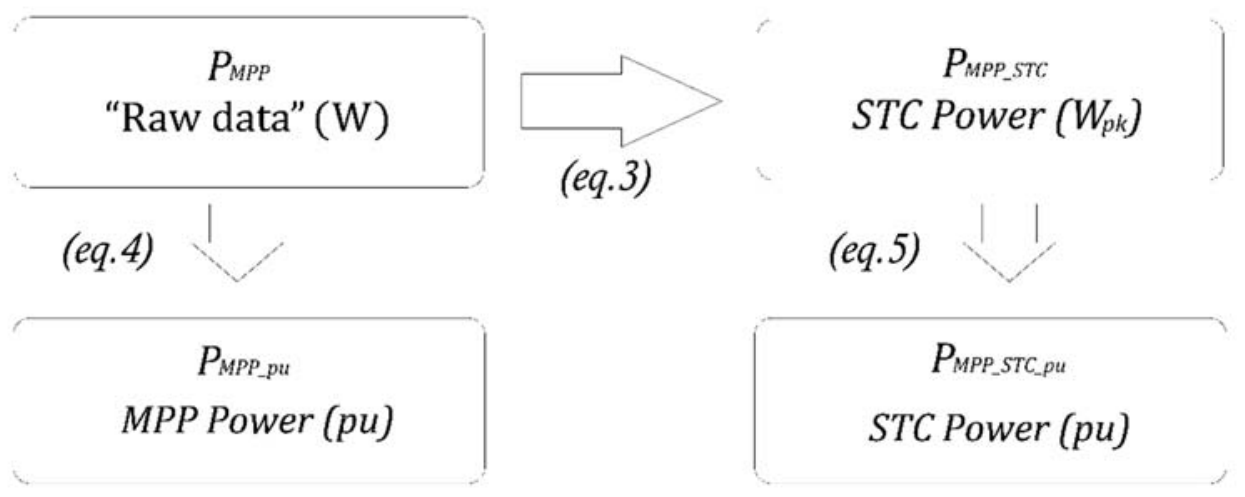


Fig. 4. Flow chart showing the procedure followed to calculate normalized powers.

Fig. 5 includes, for the beginning of operation of ETSID PV plant, the $P_{M P P_{-} p u}$ and its corresponding $P_{M P P_{-} S T C_{-} p u}$ values calculated by means of Eq. (3)-(5). It shows that, during midday, the $P_{M P P_{-} S T C \_p}$ is a much more reliable and stable parameter for comparing the photovoltaic modules due to the correction of the irradiation and temperature.

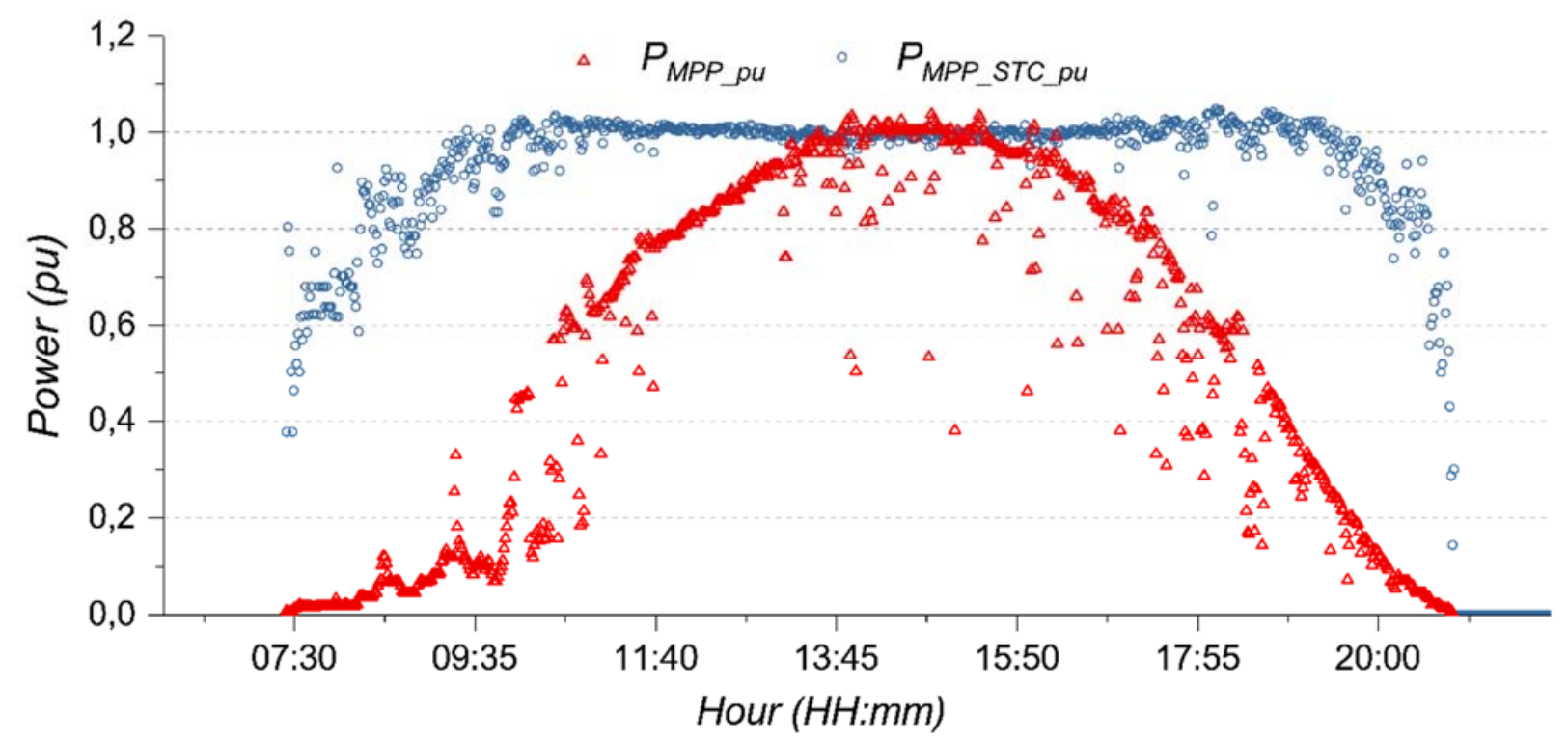

Fig. 5. $P_{M P P_{\_} \text {pu }}$ and $P_{M P P_{-} S T C \_ \text {p }}$ values for the beginning of the operation in ETSID PV plant.

The study of the evolution of the normalized $P_{M P P_{-} p u}$ and $P_{M P P_{-} S T C} p u$ values was performed during one year. After filtering the raw data $\left(G I>700 \mathrm{~W} / \mathrm{m}^{2}\right.$ and $\left.\Delta G I<20 \mathrm{~W} / \mathrm{m}^{2} / \mathrm{min}\right)$, approximately one measure per day was used to carry out the analysis. The values selected enabled adequate values to be found until winter (due to climatic conditions of Valencia). Fig. 6 shows the values of the normalized $P_{M P P_{-} p u}$ and $P_{M P P_{-} S T C} p u$ plus the irradiance for the first months of operation of the ETSID PV plant. The $P_{M P P_{-} S T C \_}$values enable an analysis to be made of the stabilization of both PV plants, as well as a study of the main factors in this stabilization process. 


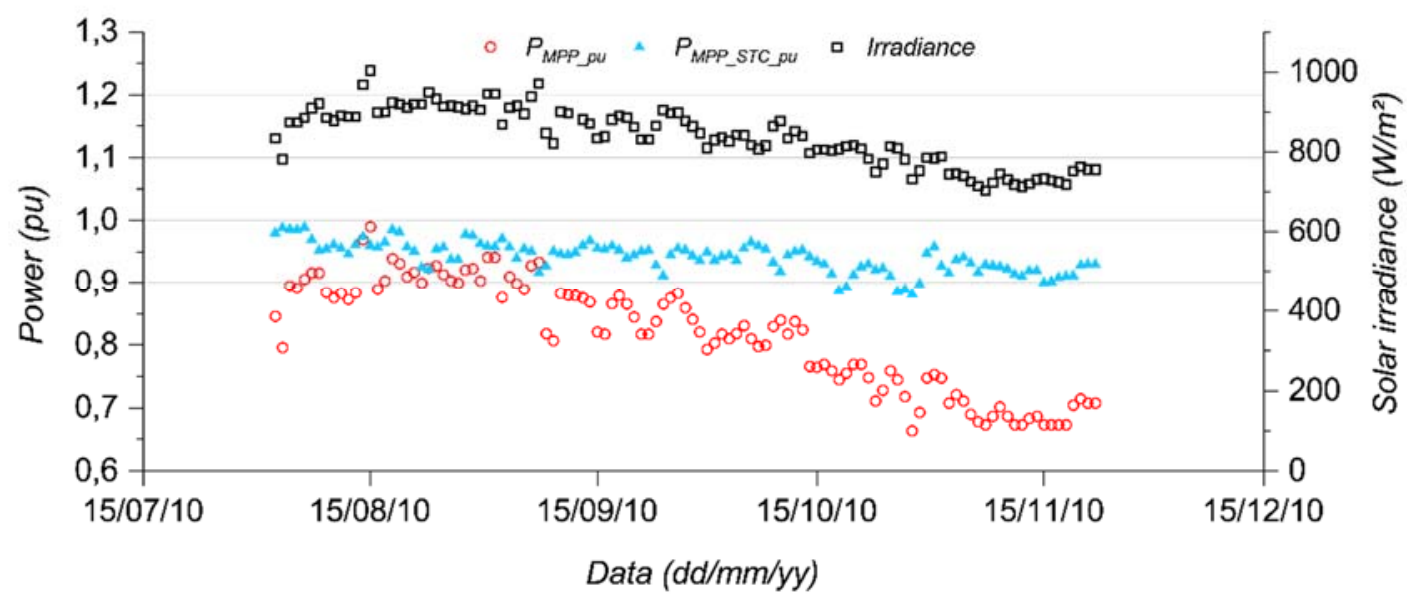

Fig. 6. Irradiance, PMPP_STC_pu, and PMPP_pu for the first four months of operation in ETSID PV plant.

$P_{M P P_{-} S T C_{\perp} p u}$ values for the first year of performance of both facilities has been gathered and statistically analyzed. Maximum $P_{M P P_{-} S T C} p u$ values are obtained at the startup of the PV plants, with a value equal to 1.036 pu for ETSID and $1.042 \mathrm{pu}$ for NEXUS. The limit of maximum over-power detailed by the manufacturer is $+20 \%$, far from the results obtained in both PV plants. The average value of $P_{M P P_{-} S T C} p u$ at the end of the first year is around $0.91 \mathrm{pu}$ of the nominal manufacturer's value. Table 5 shows the main parameters of the $P_{M P P_{-} S T C} p u$ values analyzed for ETSID and NEXUS. It is appreciated that both facilities reach similar average values: $0.912 \pm 0.034$ pu for ETSID and $0.902 \pm 0.043$ pu for NEXUS PV plant.

\section{Table 5.}

Statistical parameters for calculated $P_{M P P_{-} S T C}$ pu values in ETSID and NEXUS.

\begin{tabular}{|c|c|c|}
\hline & ETSID & NEXUS \\
\hline Average $P_{M P P_{-} S T C_{-} p}$ & 0.912 & 0.902 \\
\hline Standard deviation & 0.034 & 0.043 \\
\hline Coefficient of variation & $3.768 \%$ & $4.822 \%$ \\
\hline Minimum & 0.872 & 0.830 \\
\hline Maximum & 1.036 & 1.042 \\
\hline
\end{tabular}

The stabilization process of the two plants is analyzed by means of the variation of $P_{M P P_{-} S T C} p u$ during the first months of operation as a function of incoming accumulated irradiation in PSH. Fig. 7 presents the evolution of $P_{M P P_{-} S T C_{\perp} p u}$ in both installations and reveals some similarities. In both cases, there are three different regions in the graphs. In region a (from the beginning of PV plant operation until $200 \mathrm{PSH}$ ) the $P_{M P P} S T C$ p $p$ values showed a rapid decrease from initial power. Region b (extending approximately from 200 PSH to $1150 \mathrm{PSH}$ ) shows a smaller slope. In region c, the behavior of both PV plants shows a large discrepancy in the $P_{M P P_{-} S T C}{ }_{-} u$ evolution. 


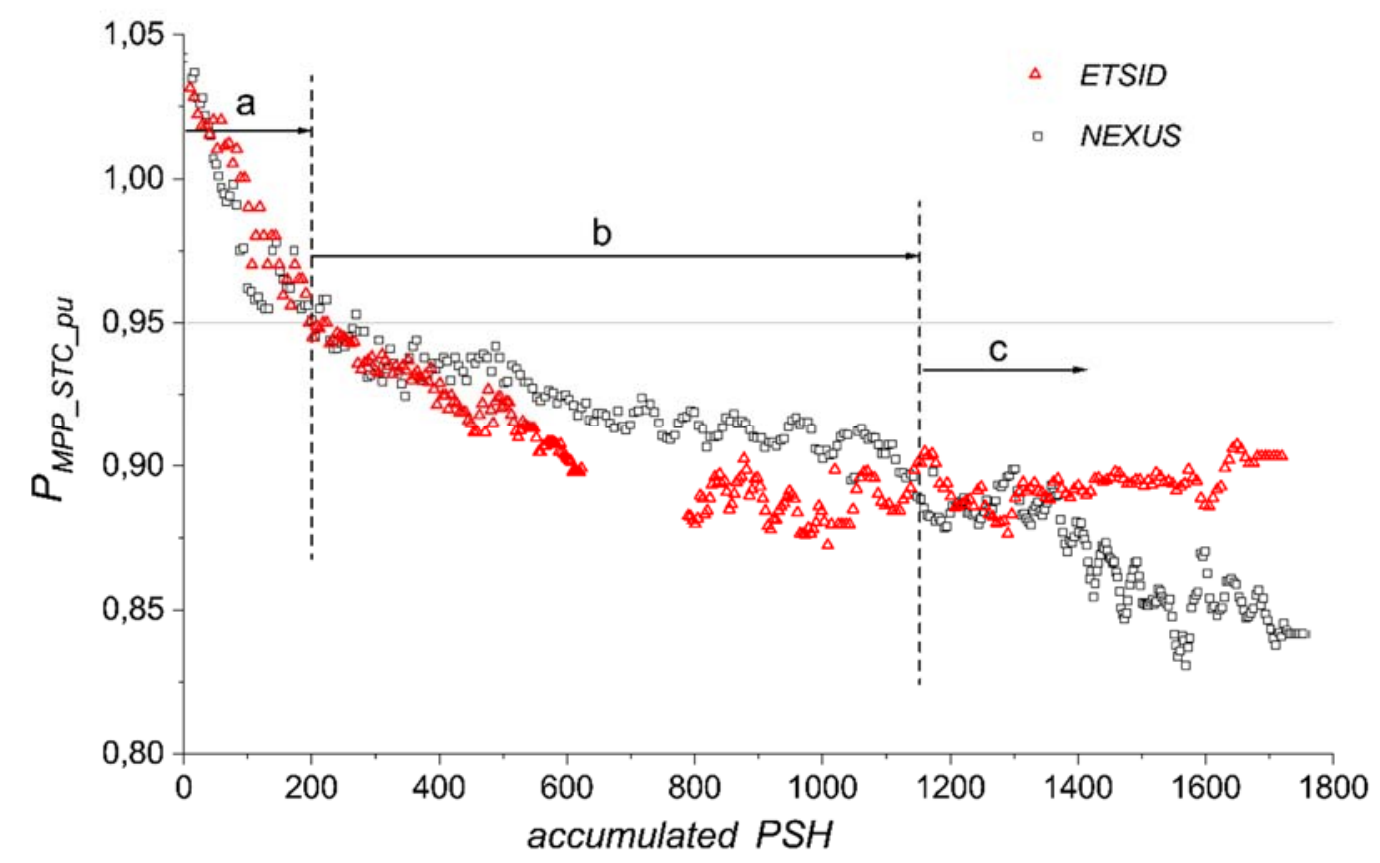

Fig. 7. Evolution of $P_{M P P \_S T C}$ pu in NEXUS and ETSID PV plants during the first year with respect to accumulated PSH.

For values of PSH greater than 1150 PSH, approximately after eight months of operation, each PV plant behaved differently. ETSID showed a small recovery in $P_{M P P} S T C$ p $u$ values while the NEXUS installation showed a decrease in the $P_{M P P_{S} S T C} p u$ values. The small recovery in the ETSID PV plant is explained by means of the seasonal variations in a-Si:H modules, as reported in [61-63]. A thermal annealing phenomenon occurs when a-Si:H modules are exposed to high temperatures (summer months), inducing a reversible process in which the hydrogen atoms return to their original position. Because of this phenomenon, the PV plant output power shows a decline combined with a sinusoidal variation. This sinusoidal evolution, depending on the climatic conditions, has been reported to occur between the first six to ten months of continuous outdoor exposure and with an accumulated irradiation of around 1000 PSH. The NEXUS plant started its operation in April at the beginning of the spring. The ETSID plant started to generate energy at the end of July (the hottest month in Valencia). The use of normalized power enables a comparison of the behavior of both installations. It can be seen that PV modules first exposed in a low radiation season (NEXUS) reach similar light induced stabilization values as those that were first exposed during the months of highest irradiance and irradiation (ETSID). The difference between both curves in the time scale is due to the slower and more stable evolution of the ETSID plant. The 200 PSH level is reached in NEXUS after 40 days of operation, while the same level was reached in ETSID after just 33 days.

\section{Analysis of the stabilization process by means of the exposure-response relationship}


Because the $P_{M P P_{-} S T C}$ pu values show two different regions before reaching the stationary state, it is considered that two effects in the a-Si:H modules cause these two time regimes. Hence, it is of interest to analyze the LID effect by using exposure-response mathematical functions, also known as the dose-response relationship. An exposure-response mathematical function is a type of analysis that is widely employed in diverse scientific fields [64-68]. In the most general case, they are used as combined dose-time-response models. They are employed to describe the temporal variation of a representative magnitude in an object population, as influenced by variation in the magnitude of an effector agent [64-68]. Depending on the field, the "population" may represent humans, other biological lifeforms in ecological systems, farm lands, chemical compounds, enzymes, etc. Dose-response models are used to describe the effect of the amount of a toxin or a therapeutic drug on survival in biological communities; the combined effect of inhibitors on enzymes [69]; the relationships among exposure time, concentration, and toxicity of insecticides [70]; the quantity of applied fertilizer on agricultural yield [71]; the relationship between herbicide dose and plant response [72]; the decomposition kinetics [73] or the polymorphic transformations of solids [74], the voltage dependent activation of ion channels [75]; the concentration of antioxidants on the oxidative stability of organic materials, etc. The logistic equation [76] assumes that the transformation rate is proportional to both the transformed and the untransformed substrate. It predicts that the transformation initially proceeds exponentially, then slows and eventually saturates.

Stabilization levels of PMM and radiation dosages for the PV plants after a certain exposure time can be calculated by studying the exposure-response relations and by developing the corresponding models. Some reports exist where polynomial correlation or exponential and logarithmic functions were used to explain the stabilization curve of the output power during the first months of operation [77]. The novelty of the exposure-response approach is that it gives an adequate description of the stabilization process observed in both PV plants under analysis.

In this study, exposure-response relationships depend on exposure time and exposure configuration (e.g., GI, $T_{a m b}$, $T_{\text {cell, }}$, wind, etc.). Quantifying the response after a different exposure time, or for a different configuration, leads to a modified relationship; and to altered conclusions about the effects of the external stimulus under consideration. This limitation is caused by the complexity of systems composed of different materials and the often unknown recombination processes operating between the external exposure and the material response (that in our study is dominated by the Staebler-Wronski effect) [45]. Taking in account that two effector agents are present in the a-Si:H modules, we have considered a two-terms exposure-response mathematical function described in Fig.8: 


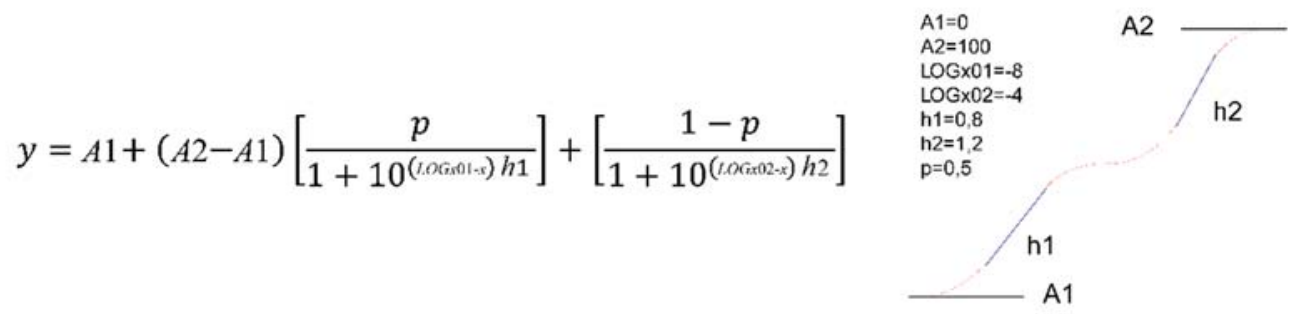

Fig. 8. Generic example of the exposure-response mathematical function for a given set of parameters A1, A2, LOGX01, $\log 02, h 1, h 2$ and $p$.

The parameters that appear in the exposure-response function are identified with the phenomenon under study, being the $P_{M P P_{-} S T C}$ pu the dependent variable, and the $P S H$ the independent variable. The expression obtained after the identification of the parameters is as follows:

$$
y=P_{S}+\left(P_{i}-P_{S}\right)\left[\frac{p}{1+10^{(C 1-X) m 1}}\right]+\left[\frac{1-p}{1+10^{(C 2-X) m 2}}\right]
$$

Where the information analyzed from our model comes from $P_{s}$ is stabilized $P_{M P P_{-} S T C \_p u} ; P_{i}$ is the initial $P_{M P P_{-} S T C \_p u}$; $C 1$ is the middle PSH value of the point for the evolution shown by the first slope; $C 2$ is the middle $P S H$ value of the point for the evolution shown by the second slope; $\mathrm{m} 1$ and $\mathrm{m} 2$ being the corresponding slopes in $\mathrm{m}^{2} / \mathrm{kWh} ; p$ is the weight of each of the two terms used for adjustment; and R-square is the coefficient of determination calculated from the statistical fitting. Parameters used for fitting the experiments are detailed in Table 6. Fig. 9 shows the resulting graphical representation together with the values of $P_{M P P_{-} S T C} p u$ obtained after the data filtering and normalization.

Table 6.

System parameters fitted for the two PV plants.

\begin{tabular}{|l|c|c|c|c|c|c|c|c|}
\hline & $P_{s}$ & $P_{i}$ & $C 1\left(\mathrm{kWh} / \mathrm{m}^{2}\right)$ & $C 2\left(\mathrm{kWh} / \mathrm{m}^{2}\right)$ & $m 1\left(\mathrm{~m}^{2} / \mathrm{kWh}\right)$ & $m 2\left(\mathrm{~m}^{2} / \mathrm{kWh}\right)$ & $p$ & $R$-square \\
\hline ETSID & 0.8833 & 1.043 & 104.76607 & 510.02874 & -0.00842 & -0.00316 & 0.6077 & 0.981 \\
\hline NEXUS & 0.9084 & 1.042 & 65.46899 & 373.29305 & -0.02136 & -0.00238 & 0.5463 & 0.964 \\
\hline
\end{tabular}

Exposure to intense sunlight for prolonged time decreases the efficiency of a-Si:H solar cells by up to $30 \%$ : an effect that is referred to as the Staebler-Wronski effect. In accordance with M. Fehr et al. [40], it is necessary to distinguish between metastable light-induced defects that can be removed by annealing at moderate temperatures $\left(100-200{ }^{\circ} \mathrm{C}\right.$ for $1-$ 2h) $[44,78]$, and defects present after deposition (native defects) that are stable with respect to annealing up to the deposition temperature. A wide variety of models had been proposed to explain the Staebler-Wronski effect, but its microscopic process still remains unclear due to the presence of many microvoids and vacancies in the a-Si:H layers $[38,78,79]$. 

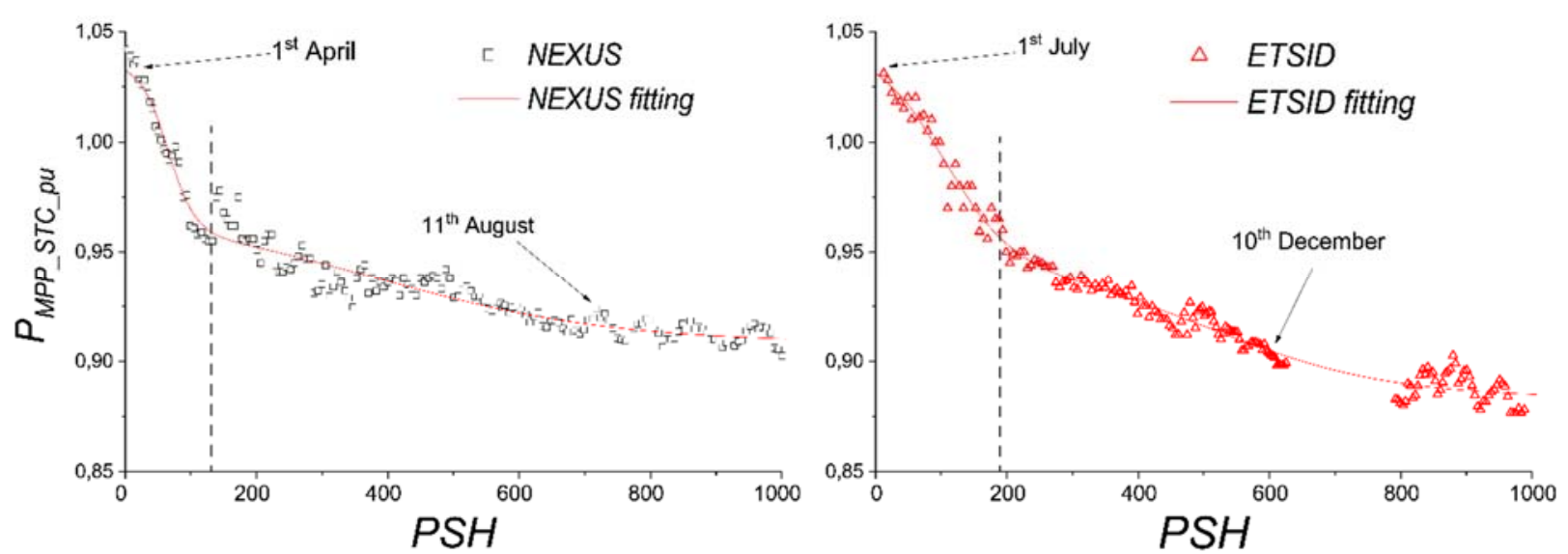

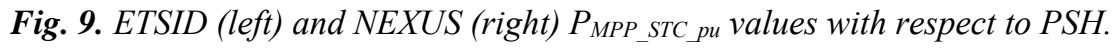

From the analysis of the experimental data shown in Fig. 9 and considering the bibliographic studies presented, it is reasonable to believe that until $1000 \mathrm{PSH}$ (around seven working months for the two PV plants) the presence of two types of defect populations can be detected. How they will modulate the performance of the modules is also influenced by the accumulated irradiation over time. In Fig. 9 the first evolution in the a-region is characterized by a slope greater than the corresponding slope in the b-region. In the b-region the slopes are quite similar for both installations, as confirmed by the parameter values, $m 2_{E T S I D}$ and $m 2_{N E X U S}$, shown in the Table 6 . The differences in the startup date of each PV plant (ETSID at the end of July and NEXUS at the beginning of April) and the different $T_{a m b}$ conditions (colder in April than in July), induce an absolute slope $m 1_{\text {Nexus }}$ almost three times greater for the NEXUS installation $\left(/ m 1_{\text {NEXUS }} /=0.02136 \mathrm{~m}^{2} / \mathrm{kWh}\right)$ compared with $/ m 1_{E T S I D} /=0.00842 \mathrm{~m}^{2} / \mathrm{kWh}$. The final stabilization of $P_{M P P_{-} S T C}$ pu at around 0.9 is reached more slowly in the first months for the ETSID installation. According to the fittings used, it is found that $/ \mathrm{m} 2_{E T S I D} /=0.0032 \mathrm{~m} / \mathrm{kWh}$ is greater than $/ m 2_{N E X U S}=0.0024 \mathrm{~m}^{2} / \mathrm{kWh}$. This is explained by the fact that from $200 \mathrm{PSH}$ until $1150 \mathrm{PSH}$ the ETSID modules are working during the coldest months of the year - while that interval of PSH in Nexus PV plant occurs during the hottest months.

It can be inferred that different defect populations are present in the a-Si:H material before they are exposed to solar radiation. But clearly the first type (D1) of metastable defects acquire its stable configuration after the first irradiation exposures (less than $200 \mathrm{PSH}$ for both platforms); and a second type (D2) of metastable defects (still present in region b) evolves to stables values around 800 PSH. Evolution of values in Fig. 9 shows that a periodic oscillation starts just before arriving at the value of $800 \mathrm{PSH}$. This value of $800 \mathrm{PSH}$ is an experimental data. According to the fitting model, the stable value of $P_{M P P_{-} S T C_{-} p u}$ is reached for a $P_{s}$ parameter between 0.88 and 0.90 . The $p$ parameter used in the fitting tell us that the population of defects D1, which first reaches its stable configuration, is only slightly greater than the subsequent evolution 
of D2. Bearing in mind the results presented, and according to this analysis, a model of evolution is proposed during the first 7-8 months of implementation of the a-Si:H photovoltaic modules, given by the exposure-response mathematical function described by Eq. (6). This function better describes the experimental behavior obtained by the monitoring system than other functions detailed in [77], and represents a novelty in the field of fitting function for the analysis of the initial stabilization of the PV cell efficiency under real outdoor conditions.

\section{PV efficiency variation in the first year of operation}

An analysis of the PV efficiency completes the characterization of the PV installations. Fig. 10 shows a comparison of the efficiency of the modules in one day at the beginning of the study ("day 1") and in another day at the end of the study (“day 365”) for ETSID PV plant. A typical sunny day was chosen in the week of initial deployment of the PV array and in the same week one year later (values of irradiance exceeding $700 \mathrm{~W} / \mathrm{m}^{2}$ at midday in PV plane). Using the PV field MPP power and the irradiance given by the monitoring system and knowing the area of the PV field $\left(A_{P V}\right)$, the instantaneous efficiency of the PV field can be calculated as follows:

$$
\eta_{P V}=\frac{P_{M P P}}{G I * A_{P V}}
$$

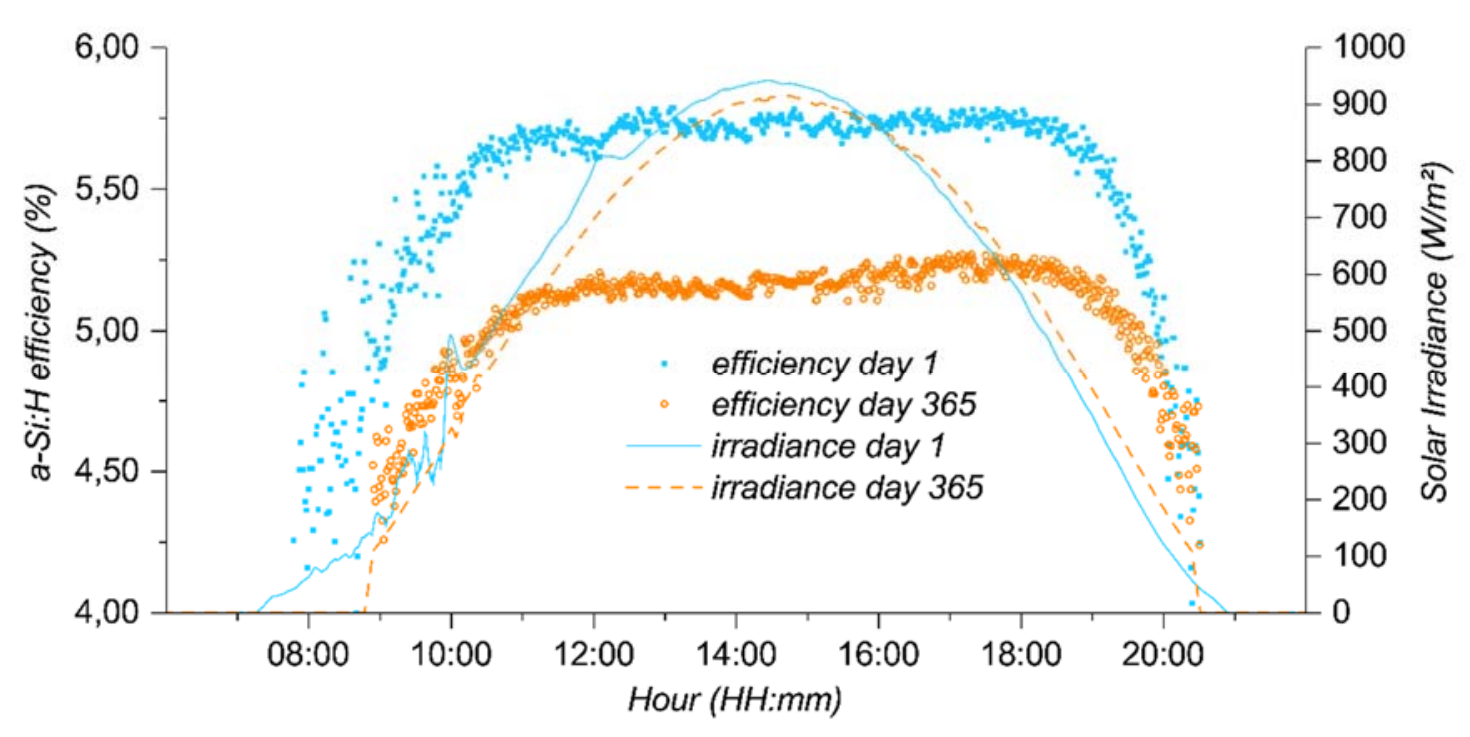

Fig. 10. Efficiency and irradiance in a typical sunny day for one of the first operating days, and a year later (ETSID PV plant).

It can be seen in Fig. 10 that average values for the efficiency of day 1 are around $5.72 \%$ and contrasting with cell efficiency maximum initial values shown in Table 1 of $6.25 \%$ for ETSID PV modules (in accordance with flash-test report). The statistical uncertainty in the estimation of the efficiency can be extracted from the data presented in Fig. 10, 5.72 \pm 0.07 
for day 1 and $5.18 \pm 0.07$ for day 365 . This uncertainty value is lower than the one obtained from the sensor tolerances ( $1 \%$ for power and $5 \%$ for irradiance, attending to manufacturer datasheet), estimated around $6 \%$ using linear error propagation in eq. (7), $5.72 \pm 0.34$ for day 1 and $5.18 \pm 0.31$ for day 365 . This difference shows that actual sensor tolerances are lower than tolerances provided in the datasheets. This behavior is also seen in Fig. 5 in which $P_{M P P_{-} S T C \_p u}$ power values show a statistical uncertainty lower than $1 \%$. Therefore, it is considered the statistical uncertainty observed as the accuracy in the efficiency estimation.

Fig. 11 represents the cell efficiency values obtained from flash-test report in the ETSID PV plant, where an average cell efficiency of $6.25 \%$ is obtained. A difference of $0.5 \%$ is observed when flash-test report values are compared with the values obtained for day 1 . Moreover, the modules were exposed to irradiance for one week while the PV plants were being built. The MPP measurements were made using different equipment: the flash-test report uses a solar simulator in controlled conditions in the factory and the MPP values for the first day correspond to the $P_{M P P}$ fixed by a grid-connected inverter under real outdoor conditions.

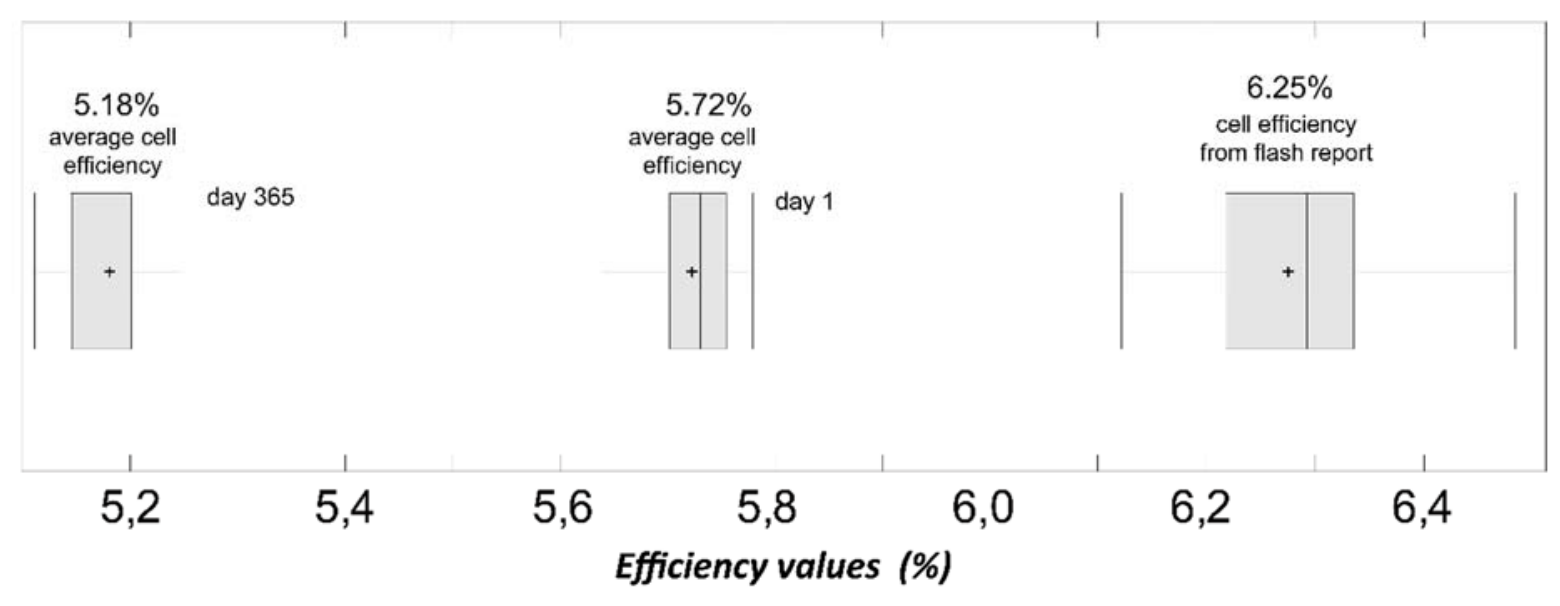

Fig. 11. Graph shows the cell efficiency from the flash-report, average cell efficiency for midday of one the first days of operation - and average cell efficiency one year later (ETSID PV plant).

Fig. 11 also includes the value of the average cell efficiency after one year of operation of the ETSID PV plant. This average cell efficiency is equal to $5.18 \%$, and so there is a yearly degradation of about $0.52 \%$ in cell efficiency when compared with the cell efficiency obtained from experimental measures during one of the first days of operation. This decrease of $0.52 \%$ represents a decrease of approximately $10 \%$ in MPP power values in the period of one year $\left(4.9 \mathrm{~W}_{\mathrm{pk}}\right.$ per each module in average values). 


\section{Conclusions}

Two grid-connected a-Si:H photovoltaic arrays were used for the evaluation of initial stabilization under natural sunlight in outdoor conditions. Light induced degradation was characterized for the more important module performance parameters. The use of a per-unit approach enables a comparison of the results of PV plants with different MPP power sizes. This characterization leads to the following conclusions:

- Maximum MPP power under STC conditions at the startup of both installations is below the maximum values given in the datasheet. While manufacturer details that describe over-power reach values of $20 \%$, the values measured and analyzed in the PV installations produce an over-power value equal to $3.6 \%$ in the ETSID installation and $4.2 \%$ in the NEXUS installation.

- Average normalized MPP power under STC conditions for the first operating year of the photovoltaic facilities is around $91 \% \pm 3 \%$ of nominal manufacturer values for ETSID and $90 \% \pm 4 \%$ for NEXUS (Table 5). Both are below the values detailed in the datasheet $\left(52 \mathrm{~W}_{\mathrm{pk}} \pm 3 \%\right)$.

- Stabilization of a-si:H modules occurs equally for modules deployed in the summer or winter when output power is analyzed with respect to the number of PSH of exposition of the PV plant. Output power stabilized values are statistically very nearly independent if the first exposition is made in a month with low PSH (NEXUS) or in one of the months with the maximum number of PSH in the year (ETSID). An initial interval of rapid power decrease is identified from the beginning of the PV operation until 200 PSH. A second interval presenting a smaller slope is found from $200 \mathrm{PSH}$ to $1150 \mathrm{PSH}$.

- The kinetics of the light induced stabilization process occurs at different speeds - with initial summer exposure causing a faster reduction in the output power. The startup of a PV plant in months with lower irradiance and irradiation levels produces a slower and more stable speed in the light-induced stabilization process. The analysis of the initial stabilization of a-Si PV plants by means of the accumulated PSH, instead of a time scale, enables similarities to be found that can be applied in other PV plants that start operation in different moments of the year.

- The comparison of the MPP power values in one of the first days of operation, and one year later, produces a decrease of approximately $10 \%$ in MPP power values in the period of one year. This decrease is equivalent to a diminution of $0.5 \%$ in the cell efficiency in the first year of operation. Another $10 \%$ of difference is observed when MPP power values in one of the first days of operation are compared with the average MPP power values obtained from the flash-test report.

The exposure-response fitting function, applied to the study of the initial stabilization in a-Si:H photovoltaic modules, represents a novelty approach linking the underlying physical effects with the efficiency decrease. This approach 
could also be applied by researchers working with other thin-film technologies. Prior to system installation, it also provides all the information required - when considering the metastable behavior of these technologies - during the design and sizing of thin-film PV plants. The exposure-response fitting function applied over the experimental measures indicates that two different agents, or defect populations, are present when the modules starts working. The two defect populations will reach a stable configuration depending on the incoming irradiation in PSH. As a result of the performed analysis and results obtained, it can be stated that exposure-response function enables a better characterization and explanation of the plant stabilization process than other fitting functions - and identifies the length of time needed to reach stable behavior.

\section{Acknowledgements}

This work was supported by Generalitat Valenciana (PROMETEOII/2014/059) and Spanish MINECO (Ministry of Economy and Competitiveness TEC2014-53727-C2-1-R).

C. Mateo is in the Escuela Técnica Superior de Ingeniería del Diseño, M.A. Hernández-Fenollosa is in the Instituto de Tecnología de Materiales; Á. Montero is in the Departamento de Termodinámica Aplicada, and, S. Seguí-Chilet is in the Instituto Interuniversitario de Investigación de Reconocimiento Molecular y Desarrollo Tecnológico.

\section{References}

[1] S. Su, T. Liu, Y. Wang, X. Chen, J. Wang, J. Chen, Performance optimization analyses and parametric design criteria of a dye-sensitized solar cell thermoelectric hybrid device, Appl. Energy. 120 (2014) 16-22. doi:10.1016/j.apenergy.2014.01.048.

[2] M.L. Bustamante, G. Gaustad, Challenges in assessment of clean energy supply-chains based on byproduct minerals: A case study of tellurium use in thin film photovoltaics, Appl. Energy. 123 (2014) 397-414. doi:10.1016/j.apenergy.2014.01.065.

[3] K. Menoufi, D. Chemisana, J.I. Rosell, Life Cycle Assessment of a Building Integrated Concentrated Photovoltaic scheme, Appl. Energy. 111 (2013) 505-514. doi:10.1016/j.apenergy.2013.05.037.

[4] F. Manzano-Agugliaro, A. Alcayde, F.G. Montoya, A. Zapata-Sierra, C. Gil, Scientific production of renewable energies worldwide: An overview, Renew. Sustain. Energy Rev. 18 (2013) 134-143.

doi:http://dx.doi.org/10.1016/j.rser.2012.10.020.

[5] I. FraunhoferInstitute for Solar Energy Systems, Photovoltaics report, 2016. https://www.ise.fraunhofer.de/content/dam/ise/de/documents/publications/studies/Photovoltaics-Report.pdf.

[6] H.W. Schock, Thin film photovoltaics, Appl. Surf. Sci. 92 (1996) 606-616. doi:10.1016/0169-4332(95)00303-7.

[7] M.A. Green, Thin-film solar cells: Review of materials, technologies and commercial status, J. Mater. Sci. Mater. Electron. 18 (2007) 15-19. doi:10.1007/s10854-007-9177-9.

[8] W. Hoffmann, T. Pellkofer, Thin films in photovoltaics: Technologies and perspectives, Thin Solid Films. 520 (2012) 4094-4100. doi:10.1016/j.tsf.2011.04.146.

[9] W. Hermes, D. Waldmann, M. Agari, K. Schierle-Arndt, P. Erk, Emerging thin-film photovoltaic technologies, 
Chemie-Ingenieur-Technik. 87 (2015) 376-389. doi:10.1002/cite.201400101.

[10] P.A. Basore, Understanding manufacturing cost influence on future trends in silicon photovoltaics, IEEE J. Photovoltaics. 4 (2014) 1477-1482. doi:10.1109/JPHOTOV.2014.2358081.

[11] R.D. McConnell, T. Surek, C.E. Witt, Progress in PV manufacturing technologies, Renew. Energy. 15 (1998) 502-505. doi:10.1016/s0960-1481(98)00213-4.

[12] I.I. energy Agency, Trends 2016 In photovoltaic applications, 2016. http://ieapvps.org/fileadmin/dam/public/report/national/Trends_2016___mr.pdf.

[13] E. Skoplaki, J. a. Palyvos, On the temperature dependence of photovoltaic module electrical performance: A review of efficiency/power correlations, Sol. Energy. 83 (2009) 614-624. doi:10.1016/j.solener.2008.10.008.

[14] S. Dubey, J.N. Sarvaiya, B. Seshadri, Temperature dependent photovoltaic (PV) efficiency and its effect on PV production in the world - A review, Energy Procedia. 33 (2013) 311-321. doi:10.1016/j.egypro.2013.05.072.

[15] M.A. Green, K. Emery, Y. Hishikawa, W. Warta, Solar cell efficiency tables (version 37), Prog. Photovoltaics Res. Appl. 19 (2011) 84-92. doi:10.1002/pip.1088.

[16] D.E. Carlson, C.R. Wronski, Amorphous silicon solar cell, Appl. Phys. Lett. 28 (1976) 671-673. doi:10.1063/1.88617.

[17] E.A. Schiff, S. Hegedus, X. Deng, Amorphous Silicon-Based Solar Cells, 2011. doi:10.1002/9780470974704.ch12.

[18] C. Shou, Z. Luo, T. Wang, W. Shen, G. Rosengarten, W. Wei, C. Wang, M. Ni, K. Cen, Investigation of a broadband TiO 2 / SiO 2 optical thin-film filter for hybrid solar power systems, Appl. Energy. 92 (2012) 298-306. doi:10.1016/j.apenergy.2011.09.028.

[19] M.A. Hamdy, S.H. El-Hefnawi, Effect of spectrally selective liquid absorption-filters on silicon solar-cells, Appl. Energy. 35 (1990) 177-188. doi:10.1016/0306-2619(90)90067-N.

[20] M.P. Brennan, A.L. Abramase, R.W. Andrews, J.M. Pearce, Effects of spectral albedo on solar photovoltaic devices, Sol. Energy Mater. Sol. Cells. 124 (2014) 111-116. doi:10.1016/j.solmat.2014.01.046.

[21] D. Dirnberger, B. Müller, C. Reise, On the uncertainty of energetic impact on the yield of different PV technologies due to varying spectral irradiance, Sol. Energy. 111 (2015) 82-96. doi:10.1016/j.solener.2014.10.033.

[22] J.I. Pankove, D.E. Carlson, Electrical and Optical Properties of Hydrogenated Amorphous Silicon, Annu. Rev. Mater. Sci. 10 (1980) 43-63. doi:10.1146/annurev.ms.10.080180.000355.

[23] S.A. Kalogirou, R. Agathokleous, G. Panayiotou, On-site PV characterization and the effect of soiling on their performance, Energy. 51 (2013) 439-446. doi:10.1016/j.energy.2012.12.018.

[24] F.A. Mejia, J. Kleissl, Soiling losses for solar photovoltaic systems in California, Sol. Energy. 95 (2013) $357-363$. doi:10.1016/j.solener.2013.06.028.

[25] D.G. Lorente, S. Pedrazzi, G. Zini, A. Dalla Rosa, P. Tartarini, Mismatch losses in PV power plants, Sol. Energy. 100 (2014) 42-49. doi:10.1016/j.solener.2013.11.026.

[26] D.C. Jordan, S.R. Kurtz, Photovoltaic degradation rates - An Analytical Review, Prog. Photovoltaics Res. Appl. 21 (2013) 12-29. doi:10.1002/pip.1182.

[27] R. Paolini, M. Zinzi, T. Poli, E. Carnielo, A.G. Mainini, Effect of ageing on solar spectral reflectance of roofing membranes: Natural exposure in Roma and Milano and the impact on the energy needs of commercial buildings, Energy Build. 84 (2014) 333-343. doi:10.1016/j.enbuild.2014.08.008.

[28] B. Figgis, A. Ennaoui, S. Ahzi, Y. Rémond, Review of PV soiling particle mechanics in desert environments, 
Renew. Sustain. Energy Rev. 76 (2017) 872-881. doi:10.1016/j.rser.2017.03.100.

[29] M. Graetzel, R.A.J. Janssen, D.B. Mitzi, E.H. Sargent, Materials interface engineering for solution-processed photovoltaics., Nature. 488 (2012) 304-12. doi:10.1038/nature11476.

[30] J.A. Mazer, An introduction to crystalline photovoltaic technology, Kluwer Acad. Publ. Bost. (1997) 151-153.

[31] T. Al Hanai, R.B. Hashim, L. El Chaar, L.A. Lamont, Environmental effects on a grid connected $900 \mathrm{~W}$ photovoltaic thin-film amorphous silicon system, Renew. Energy. 36 (2011) 2615-2622. doi:10.1016/j.renene.2010.06.010.

[32] C. Radue, E.E. van Dyk, A comparison of degradation in three amorphous silicon PV module technologies, Sol. Energy Mater. Sol. Cells. 94 (2010) 617-622. doi:10.1016/j.solmat.2009.12.009.

[33] I. Geisemeyer, F. Fertig, W. Warta, S. Rein, M.C. Schubert, Prediction of silicon PV module temperature for hot spots and worst case partial shading situations using spatially resolved lock-in thermography, Sol. Energy Mater. Sol. Cells. 120 (2014) 259-269. doi:10.1016/j.solmat.2013.09.016.

[34] S. Janke, S. Pingel, S. Wendlandt, R. Alam, Comparison of Hot Spot Endurance Tests: Temperature Behavior of Bare Vs. Encapsulated Crystalline Silicon Cells, en: 29th Eur. Photovolt. Sol. Energy Conf. Exhib., 2014: pp. 3153-3156.

[35] F.C. Krebs, Fabrication and processing of polymer solar cells: A review of printing and coating techniques, Sol. Energy Mater. Sol. Cells. 93 (2009) 394-412. doi:10.1016/j.solmat.2008.10.004.

[36] T. Ikegami, T. Maezono, F. Nakanishi, Y. Yamagata, K. Ebihara, Estimation of equivalent circuit parameters of PV module and its application to optimal operation of PV system, Sol. Energy Mater. Sol. Cells. 67 (2001) 389395. doi:10.1016/S0927-0248(00)00307-X.

[37] F. Kohler, T. Zimmermann, S. Muthmann, A. Gordijn, R. Carius, Structural order and staebler-wronski effect in hydrogenated amorphous silicon films and solar cells, IEEE J. Photovoltaics. 4 (2014) 4-9. doi:10.1109/JPHOTOV.2013.2287911.

[38] H. Fritzsche, Development in understanding and controling the Staebler-Wronski Effect in a-Si:H, Annu. Rev. Mater. Res. 31 (2001) 47-79. doi:10.1146/annurev.matsci.31.1.47.

[39] T. Shimizu, Staebler-Wronski Effect in Hydrogenated Amorphous Silicon and Related Alloy Films, Jpn. J. Appl. Phys. 43 (2004) 3257-3268. doi:10.1143/JJAP.43.3257.

[40] M. Fehr, A. Schnegg, B. Rech, O. Astakhov, F. Finger, R. Bittl, C. Teutloff, K. Lips, Metastable defect formation at microvoids identified as a source of light-induced degradation in a - Si: H, Phys. Rev. Lett. 112 (2014) 66403. doi:10.1103/PhysRevLett.112.066403.

[41] B. Von Roedern, J. a. del Cueto, Model for Staebler-Wronski Degradation Deduced from Long-Term, Controlled Light-Soaking Experiments, MRS Proc. 609 (2011) A10.4. doi:10.1557/PROC-609-A10.4.

[42] S.S. Hegedus, A. Luque, Handbook of photovoltaic science and engineering, 2003. doi:10.1002/9780470974704.

[43] E.L. Meyer, E.E. van Dyk, Characterization of degradation in thin-film photovoltaic module performance parameters, Renew. Energy. 28 (2003) 1455-1469. doi:10.1016/S0960-1481(02)00062-9.

[44] M. Stutzmann, W.B. Jackson, C.C. Tsai, Light-induced metastable defects in hydrogenated amorphous silicon: A systematic study, Phys. Rev. B. 32 (1985) 23-47. doi:10.1103/PhysRevB.32.23.

[45] D.L. Staebler, C.R. Wronski, Reversible conductivity changes in discharge-produced amorphous Si, Appl. Phys. Lett. 31 (1977) 292-294. doi:10.1063/1.89674.

[46] R. Rüther, J. Livingstone, Seasonal variations in amorphous silicon solar module outputs and thin film characteristics, Sol. Energy Mater. Sol. Cells. 36 (1995) 29-43. doi:10.1016/0927-0248(94)00165-O. 
[47] J. Merten, J. Andreu, Clear separation of seasonal effects on the performance of amorphous silicon solar modules by outdoor I /V -measurements, Sol. Energy Mater. Sol. Cells. 52 (1998) 11-25. doi:10.1016/S09270248(97)00263-8.

[48] G. Makrides, B. Zinsser, A. Phinikarides, M. Schubert, G.E. Georghiou, Temperature and thermal annealing effects on different photovoltaic technologies, Renew. Energy. 43 (2012) 407-417. doi:10.1016/j.renene.2011.11.046.

[49] E. Caamano, E. Lorenzo, R. Zilles, Quality control of wide collections of PV modules: Lessons learned from the IES experience, Prog. Photovoltaics. 7 (1999) 137-149.

[50] T. Strand, L. Mrig, R. Hansen, K. Emery, Technical evaluation of a dual-junction same-band-gap amorphous silicon photovoltaic system, Sol. Energy Mater. Sol. Cells. 41-42 (1996) 617-628. doi:10.1016/09270248(95)00132-8.

[51] G.. Smestad, Optoelectronics of solar cells, 2002.

[52] Nasa, Eosweb, (2017). https://eosweb.larc.nasa.gov/sse/ (accedido 1 de mayo de 2007).

[53] M. Hartner, A. Ortner, A. Hiesl, R. Haas, East to west - The optimal tilt angle and orientation of photovoltaic panels from an electricity system perspective, Appl. Energy. 160 (2015) 94-107. doi:10.1016/j.apenergy.2015.08.097.

[54] C. Gavazzi, Free monitor plant, eos web, (2007). http://158.42.41.254/freemonitorplant.php (accedido 1 de mayo de 2007).

[55] J.M. Shen, H.L. Jou, J.C. Wu, Novel transformerless grid-connected power converter with negative grounding for photovoltaic generation system, IEEE Trans. Power Electron. 27 (2012) 1818-1829. doi:10.1109/TPEL.2011.2170435.

[56] C. Gavazzi, Free monitor plant eos web, (2007). http://158.42.230.62/freemonitorplant.php. (accedido 20 de julio de 2005).

[57] R. Eke, A. Senturk, Monitoring the performance of single and triple junction amorphous silicon modules in two building integrated photovoltaic (BIPV) installations, Appl. Energy. 109 (2013) 154-162. doi:10.1016/j.apenergy.2013.03.087.

[58] A. Costa, M.M. Keane, J.I. Torrens, E. Corry, Building operation and energy performance: Monitoring, analysis and optimisation toolkit, Appl. Energy. 101 (2013) 310-316. doi:10.1016/j.apenergy.2011.10.037.

[59] A. Limmanee, N. Udomdachanut, S. Songtrai, S. Kaewniyompanit, Y. Sato, M. Nakaishi, S. Kittisontirak, K. Sriprapha, Y. Sakamoto, Field performance and degradation rates of different types of photovoltaic modules: A case study in Thailand, Renew. Energy. 89 (2016) 12-17. doi:10.1016/j.renene.2015.11.088.

[60] IS/IEC 61829: Crystalline Silicon Photovoltaic (PV) Array - On-Site Measurement of I-V Characteristics , (s. f.). https://archive.org/details/gov.in.is.iec.61829.1995 (accedido 25 de enero de 2016).

[61] L. Mrig, J. Burdick, W. Luft, B. Kroposki, Outdoor performance stability and controlled light-soak testing of amorphous silicon multijunction modules at NREL, en: First world Conf. Photovolt. energy Convers. (WCPEC). Waikoloa, HI, 1994: pp. 528-530.

[62] J. Chantana, A. Kamei, T. Minemoto, Influences of environmental factors on Si-based photovoltaic modules after longtime outdoor exposure by multiple regression analysis, Renew. Energy. 101 (2017) 10-15. doi:10.1016/j.renene.2016.08.037.

[63] M.A. Muñoz-García, O. Marin, M.C. Alonso-García, F. Chenlo, Characterization of thin film PV modules under standard test conditions: Results of indoor and outdoor measurements and the effects of sunlight exposure, Sol. 
Energy. 86 (2012) 3049-3056. doi:10.1016/j.solener.2012.07.015.

[64] F.J. Miller, P.M. Schlosser, D.B. Janszen, Haber's rule: A special case in a family of curves relating concentration and duration of exposure to a fixed level of response for a given endpoint, Toxicology. 149 (2000) 21-34.

doi:10.1016/S0300-483X(00)00229-8.

[65] C.I. BLISS, THE TOXICITY OF POISONS APPLIED JOINTLY, Ann. Appl. Biol. 26 (1939) 585-615. doi:10.1111/j.1744-7348.1939.tb06990.x.

[66] K.K. Rozman, J. Doull, Dose and time as variables of toxicity, Toxicology. 144 (2000) 169-178. doi:10.1016/S0300-483X(99)00204-8.

[67] V. Verma, Q.J. Yu, D.W. Connell, Evaluation of effects of long term exposure on lethal toxicity with mammals, Environ. Pollut. 185 (2014) 234-239. doi:10.1016/j.envpol.2013.11.001.

[68] M.A. Murado, M.P. González, J.A. Vázquez, Dose-response relationships: An overview, a generative model and its application to the verification of descriptive models, Enzyme Microb. Technol. 31 (2002) 439-455. doi:10.1016/S0141-0229(02)00109-6.

[69] G.K.Y. Lam, A general formulation of the concept of independent action for the combined effects of agents, Bull. Math. Biol. 56 (1994) 959-980. doi:10.1007/BF02458276.

[70] C.I. Bliss, The relation between exposure time, concentration and toxicity in experiments on insecticides, Ann. Entomol. Soc. Am. 33 (1940) 721-766. doi:10.1093/aesa/33.4.721.

[71] M. Boldea, F. Sala, H. Rawashdeh, D. Luchian, Evaluation of agricultural yield in relation to the doses of mineral fertilizers, J. Cent. Eur. Agric. 16 (2015) 149-161. doi:10.5513/JCEA01/16.2.1603.

[72] S.S. Seefeldt, J.E. Jensen, E.P. Fuerst, Log-Logistic Analysis of Herbicide Dose-Response Relationships, Weed Technol. 9 (1995) 218-227. doi:10.1017/CBO9781107415324.004.

[73] W. Ng, Thermal decomposition in the solid state, Aust. J. Chem. 28 (1975) 1169-1178. doi:https://doi.org/10.1071/CH9751169.

[74] A. Menon, S. Bhandarkar, Predicting polymorphic transformation curves using a logistic equation, Int. J. Pharm. 286 (2004) 125-129. doi:10.1016/j.ijpharm.2004.07.028.

[75] S. Chowdhury, B. Chanda, Free-energy relationships in ion channels activated by voltage and ligand, J. Gen. Physiol. 141 (2013) 11-28. doi:10.1085/jgp.201210860.

[76] J. Berkson, Application of the Logistic Function to Bio-Assay, J. Am. Stat. Assoc. 39 (1944) 357-365. doi:10.1080/01621459.1944.10500699.

[77] M.Z. Hussin, S. Shaari, A.M. Omar, Z.M. Zain, Amorphous silicon thin-film: Behaviour of light-induced degradation, Renew. Sustain. Energy Rev. 43 (2015) 388-402. doi:10.1016/j.rser.2014.10.093.

[78] M. Stutzmann, Microscopic aspects of the Staebler-Wronski effect, en: Mater. Res. Soc. Symp. - Proc., 1997: pp. 37-48. doi:10.1557/PROC-467-37.

[79] W. Beyer, W. Hilgers, P. Prunici, D. Lennartz, Voids in hydrogenated amorphous silicon materials, en: J. Non. Cryst. Solids, 2012: pp. 2023-2026. doi:10.1016/j.jnoncrysol.2011.09.030. 